\title{
A COMPARATIVE STUDY ON THE EFFECTS OF THIOPENTONE, PROPOFOL AND ETOMIDATE AS ANAESTHETIC AGENTS IN MODIFIED ELECTROCONVULSIVE THERAPY
}

\author{
Vasanthageethan Rathinam¹, Rajarajan $N^{2}$, Sivakumar $G^{3}$
}

${ }_{1}^{1}$ Associate Professor, Department of Anaesthesiology, Government Mohankumaramankalam Medical College Hospital, Salem, Tamilnadu, India.

2Senior Resident, Department of Anaesthesiology, Government Pudukkottai Medical College Hospital, Pudukkottai, Tamilnadu, India. 3Professor and HOD, Department of Anaesthesiology, Government Mohankumaramankalam Medical College Hospital, Salem, Tamilnadu, India.

ABSTRACT
BACKGROUND
Modified ECT is considered to be the standard practice worldwide. An induction agent with a rapid onset, short duration of action
and minimal adverse effects would be ideal.
Objective- We compared the profile and haemodynamic effects of the three intravenous induction agents Thiopentone, Propofol
and Etomidate in patients undergoing modified electroconvulsive therapy.

\section{MATERIALS AND METHODS}

This is a prospective observational study among 150 patients, 50 patients in each group, in the age group of 16 to 60 , who were undergoing modified electroconvulsive therapy at Government Mohankumaramangalam Medical College, Salem. After meticulous assessment and preparation, patients were shifted to ECT suite. An informed, explained and written consent was obtained. The haemodynamic parameters were recorded before induction (baseline values), immediately after induction, 1 minute after ECT, 5 minutes, 10 minutes, 15 minutes and 20 minutes after ECT. The data was entered into a proforma and statistical analysis was done using IBM SPSS version 22 . P value $<0.05$ was considered statistically significant. The primary outcome variables are systolic blood pressure, diastolic blood pressure, heart rate and seizure duration. One-Way ANOVA was used to assess statistical significance across the groups.

\section{RESULTS}

All the three groups were comparable in baseline characteristics. Change in systolic pressure is more with Propofol and Thiopentone than with Etomidate $(\mathrm{p}<0.001)$. Change in diastolic pressure is also more with Propofol and Thiopentone and Etomidate $(p<0.001)$. Change in heart rate is least in Etomidate group compared with Propofol and Thiopentone ( $p<0.001)$. Seizure duration is shortest in Propofol group and more in Etomidate group $(p<0.001)$.

\section{CONCLUSION}

Etomidate offers better haemodynamic stability and interferes less with the seizure activity, thereby increasing the seizure duration which is of utmost importance in Electroconvulsive therapy. Hence, Etomidate can be used in modified electroconvulsive therapy.

\section{KEY WORDS}

Thiopentone, Propofol, Etomidate, Modified Electroconvulsive Therapy.

HOW TO CITE THIS ARTICLE: Rathinam V, Rajarajan N, Sivakumar G. A comparative study on the effects of thiopentone, propofol and etomidate as anaesthetic agents in modified electroconvulsive therapy. J. Evolution Med. Dent. Sci. 2018;7(32):3620-3624, DOI: $10.14260 /$ jemds/2018/813

\section{BACKGROUND}

Modified ECT is considered to be the standard practice worldwide. Modified ECT refers to the practice of providing an anaesthetic agent and a muscle relaxant before ECT to minimise the intensity of motor seizures. ${ }^{1}$ Before the introduction of anaesthetic agents in ECT, unmodified or direct ECT caused a variety of musculoskeletal complications, especially compression fracture of the vertebra. ${ }^{2}$

'Financial or Other Competing Interest': None.

Submission 17-07-2018, Peer Review 29-07-2018,

Acceptance 31-07-2018, Published 06-08-2018.

Corresponding Author:

Rajarajan $N$,

Senior Resident,

Department of Anaesthesiology

Government Pudukkottai Medical College Hospital,

Pudukkottai-622004, Tamilnadu, India.

E-mail: rajarajangmkmch@gmail.com

DOI: $10.14260 /$ jemds $/ 2018 / 813$
The use of the anaesthetic agent induces sleep and prevents anxiety associated with the apnoea caused by muscle relaxant.

Since ECT is a brief procedure which is often done as outpatient procedure, an induction agent with a rapid onset, short duration of action and minimal adverse effects would be ideal. ${ }^{3-10}$

The other important property, which determines the choice of anaesthetic agent includes the alteration of seizure threshold and haemodynamic effects of the agent. ${ }^{11}$

The objectives of our study was we compared the profile and haemodynamic effects of the three intravenous induction agents Thiopentone, Propofol and Etomidate in patients undergoing modified electroconvulsive therapy. The effect of the drugs on the seizure activity is compared by measuring the seizure duration induced during the modified electroconvulsive therapy. 


\section{MATERIALS AND METHODS}

In this prospective observational study among 150 patients, the first 50 persons with each group of drugs administered for modified ECT were taken up for the study for convenience. Drug given was based on availability at various times. Convenient sampling method was used, as first 50 consented persons in each group were taken up for the study.

50 patients in each group undergoing electroconvulsive therapy with one of the anaesthetic agents (Thiopentone, Propofol and Etomidate) was chosen. The criteria for inclusion are the: (1) Age group of 16 to 60, (2) Patients with severe and drug refractory depression, schizophrenia, mania and psychosis, (3) ASA grade 1 and 2 and (4) Patients with no known risk of allergy to any of the three drugs mentioned.

Patients with-1) A history of recent cerebrovascular accident, cardiovascular conduction defects and high-risk pregnancy with history of epilepsy, 2) History of receiving lithium prior to ECT therapy and 3) Patients and relatives not willing to sign informed consent were excluded from the study.

\section{Procedure}

After meticulous preoperative assessment and adequate fasting status, patients were shifted to ECT suite. An informed explained and written consent is obtained from the relatives of the patient. All the standard monitors were connected including ECG, non-invasive blood pressure monitoring, pulse oximetry and the baseline values were noted.

All patients were given injection Glycopyrrolate $0.2 \mathrm{mg}$ intramuscularly one hour before treatment. All patients were pre-oxygenated for three minutes. Anaesthesia is induced by using either $1 \%$ Propofol $(1 \mathrm{mg} / \mathrm{kg}$ ) or $2.5 \%$ Thiopentone (3 $\mathrm{mg} / \mathrm{kg}$ ) or Etomidate $(0.2 \mathrm{mg} / \mathrm{kg})$ given over 20 seconds, through an 18-guage cannula in a vein on the dorsum of the hand. The induction dose will be considered adequate if the eyelash reflex lost after 30 seconds.

Following the onset of anaesthetic effect, depolarising muscle relaxant Succinylcholine $0.5 \mathrm{mg} / \mathrm{kg}$ will be administered. Muscle fasciculations or fine twitching movements indicate its action. The disappearance of these movements indicates that maximal relaxation has occurred. The patient's lungs will be ventilated manually with oxygen via a face mask. When adequate neuromuscular relaxation is obtained, an adequate-sized Guedel's airway is inserted.

The bitemporal electrodes are placed in the bifrontotemporal region and a brief pulse stimulus will be given for about $2 \mathrm{~m}$ sec (Voltage 90-120) to produce a seizure. Patients will be ventilated with $100 \%$ oxygen at a rate of 12 breaths per minute until spontaneous breathing returns and patients are fully recovered clinically.

The haemodynamic parameters i.e. systolic blood pressure, diastolic blood pressure, heart rate and also seizure duration was recorded before induction (baseline values), immediately after induction, 1 minute after ECT and 5 minutes, 10 minutes, 15 minutes and 20 minutes after ECT.

\section{Ethics}

The study was initiated after obtaining approval from the Institutional Ethics Committee, Government Mohan Kumaramangalam Medical College, Salem. Consent was obtained from the patients or their relatives before procedure.

\section{Statistics}

The data was entered into a proforma and statistical analysis was done using IBM SPSS version 22. P-value $<0.05$ was considered statistically significant.

The primary outcome variables are systolic blood pressure, diastolic blood pressure, heart rate and seizure duration.

Other relevant variables are age, height, weight and gender. Primary explanatory variable: Study group (Thiopentone, Propofol, Etomidate).

The association between study group and systolic blood pressure, diastolic blood pressure, heart rate, age, height and weight was assessed by comparing the mean values at each stage using One-Way Analysis of Variance (ANOVA) to assess statistical significance.

\section{RESULTS}

A total of 150 subjects were included in final analysis. Among the study population, $50(33.33 \%)$ patients were included in Thiopentone group, 50 (33.33\%) in Propofol group and 50 (33.33\%) in Etomidate. Among the study population, 50.67\% were males. The mean age was $33.83 \pm 10.37$ years in the study population.

\begin{tabular}{|c|c|c|c|c|c|c|}
\hline Parameter & $\begin{array}{c}\text { Mean } \pm \\
\text { SD }\end{array}$ & Median & Min & Max & $\begin{array}{c}\text { 95\% C.I. for } \\
\text { EXP (B) }\end{array}$ \\
\cline { 5 - 7 } & & & & Lower & Upper \\
\hline Height & $\begin{array}{c}159.27 \\
\pm 5.7\end{array}$ & 159.00 & 145.00 & 174.00 & 158.35 & 160.19 \\
\hline Weight & $\begin{array}{c}64.19 \pm \\
10.08\end{array}$ & 65.00 & 39.00 & 82.00 & 62.56 & 65.81 \\
\hline Table 1. Descriptive Analysis for Height, Weight in Study \\
Population (N= 150) \\
\hline
\end{tabular}

The mean age in Thiopentone group was $30.26 \pm 10.33$ years, $33.46 \pm 8.19$ years in Propofol group and $33.44 \pm 6.65$ years in Etomidate group. Considering Thiopentone as baseline, the mean difference of age (3.20) in Propofol group was statistically not significant $(\mathrm{P}$ value $>0.05)$ and also statistically not significant in Etomidate group (3.18) (P value $>0.05$ ).

The mean height was $159.27 \pm 5.7 \mathrm{cms}$ in the study population. The minimum height was $145 \mathrm{cms}$ and maximum height was $174 \mathrm{cms}$ in the study population $(95 \%, \mathrm{CI}=158.35$ to 160.19 ). The mean weight was $64.19 \pm 10.08 \mathrm{kgs}$ in the study population. Minimum level was $39 \mathrm{kgs}$ and maximum level was $82 \mathrm{kgs}$ in the study population $(95 \%, \mathrm{CI}=62.56$ to 65.81) (Table 1).

Among the thiopentone group, 25 (50\%) were males and remaining $25(50 \%)$ were females. Among the propofol group, 23 (46\%) were males and remaining 27 (54\%) were females. Among the etomidate group, 28 (56\%) were males and remaining 22 (44\%) were females. The difference in the proportion of study group across gender was statistically not significant (P value 0.602). 


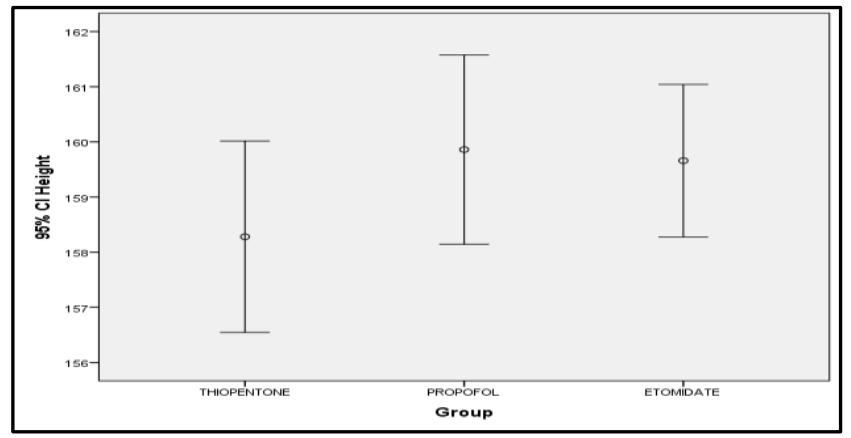

Figure 1. Comparison of Mean Height across Study Groups ( $N=150)$

\begin{tabular}{|c|c|c|c|c|}
\hline $\begin{array}{l}\text { Systolic Blood } \\
\text { Pressure }\end{array}$ & $\begin{array}{l}\text { Thiopentone } \\
\text { Mean } \pm \text { SD }\end{array}$ & \begin{tabular}{|} 
Propofol \\
Mean \pm \\
SD
\end{tabular} & \begin{tabular}{|l|} 
Etomidate \\
Mean \pm SD
\end{tabular} & $\begin{array}{c}P \\
\text { value }\end{array}$ \\
\hline Before induction & 8. & & & 0.214 \\
\hline er & & & & $<0.001$ \\
\hline 1 min after ECT & & $\begin{array}{r}129 . \\
9 .\end{array}$ & $\begin{array}{r}135 \\
9\end{array}$ & $<0.001$ \\
\hline 5 minutes & $\begin{array}{r}134 . \\
6.9\end{array}$ & $\begin{array}{c}124.02 \pm \\
8.82 \\
\end{array}$ & $\begin{array}{c}133.98 \pm \\
9.16\end{array}$ & $<0.001$ \\
\hline 10 minutes & $\begin{aligned} 129 . \\
7.5\end{aligned}$ & $\begin{array}{c}116.96 \pm \\
9.45\end{array}$ & $\begin{array}{c}129.66 \pm \\
8.53\end{array}$ & $<0.001$ \\
\hline 15 minutes & 126 & $\begin{array}{c}111.72 \pm \\
8.66\end{array}$ & $\begin{array}{c}125.48 \pm \\
9.02 \\
\end{array}$ & 0.605 \\
\hline 20 minutes & $\begin{array}{c}125.14 \pm \\
7.82\end{array}$ & $\begin{array}{c}111.46 \pm \\
7.78\end{array}$ & \begin{tabular}{|c|}
$120.4 \pm$ \\
9.39
\end{tabular} & 0.020 \\
\hline \multicolumn{5}{|c|}{$\begin{array}{l}\text { Table 2. Comparison of Systolic Blood Pressure between } \\
\text { Three Groups at Different Time Periods }(N=150)\end{array}$} \\
\hline
\end{tabular}

The mean systolic blood pressure in Thiopentone group before induction was $122.88 \pm 8.9 \mathrm{mmHg}$, it was $116.04 \pm$ $10.28 \mathrm{mmHg}$ immediately after induction, it was $142.1 \pm 7.34$ $\mathrm{mmHg}$ in 1 minute after ECT, it was $134.76 \pm 6.99 \mathrm{mmHg}$ in 5 minutes, it was $129.86 \pm 7.54 \mathrm{mmHg}$ in 10 minutes, it was $126 \pm 7.47 \mathrm{mmHg}$ in 15 minutes and $125.14 \pm 7.82$ in 20 minutes.

The mean systolic blood pressure in Propofol group before induction was $119.12 \pm 13.11 \mathrm{mmHg}$, it was $113.12 \pm$ $13.73 \mathrm{mmHg}$ immediately after induction, it was $129.44 \pm$ 9.46 in 1 minutes after ECT, it was $124.02 \pm 8.82$ in 5 minutes, it was $116.96 \pm 9.45$ in 10 minutes, it was $111.72 \pm 8.66$ in 15 minutes and $111.46 \pm 7.78$ in 20 minutes.

The mean systolic blood pressure before Etomidate group within induction was $120.14 \pm 11.62$, it was $121.76 \pm 10.41$ immediately after induction, it was $135.98 \pm 9.4$ in 1 minute after ECT, it was $133.98 \pm 9.16$ in 5 minutes, it was $129.66 \pm$ 8.53 in 10 minutes, it was $125.48 \pm 9.02$ in 15 minutes and $120.4 \pm 9.39$ in 20 minutes.

In each group, value measured before induction is considered as baseline (Table 2). We observed the initial fall in systolic blood pressure after induction in all the groups. But the fall in blood pressure is more in propofol group, which is statistically significant except at 15 minutes.

\begin{tabular}{|c|c|c|c|c|}
\hline \multirow{2}{*}{$\begin{array}{l}\text { Diastolic } \\
\text { Blood } \\
\text { Pressure }\end{array}$} & Thiopentone & Propofol & Etomidate & \multirow{2}{*}{$\begin{array}{c}P \\
\text { value }\end{array}$} \\
\hline & Mean \pm SD & $\begin{array}{l}\text { Mean } \pm \\
\text { SD }\end{array}$ & $\begin{array}{l}\text { Mean } \pm \\
\text { SD }\end{array}$ & \\
\hline $\begin{array}{c}\text { Before } \\
\text { induction }\end{array}$ & $79.18 \pm 6.56$ & $\begin{array}{c}77.44 \pm \\
6.89\end{array}$ & $\begin{array}{c}74.8 \pm \\
9.62\end{array}$ & 0.210 \\
\hline $\begin{array}{c}\text { Immediately } \\
\text { after } \\
\text { induction }\end{array}$ & $76.66 \pm 6.14$ & $\begin{array}{c}71.28 \pm \\
7.36\end{array}$ & $\begin{array}{c}72.84 \pm \\
9.14\end{array}$ & $<0.001$ \\
\hline $\begin{array}{c}1 \text { min after } \\
\text { ECT }\end{array}$ & $84.48 \pm 5.92$ & $\begin{array}{c}82.78 \pm \\
7.48\end{array}$ & $\begin{array}{l}91 \pm \\
7.53\end{array}$ & $<0.001$ \\
\hline 5 minutes & $82.96 \pm 5.45$ & $\begin{array}{c}79.28 \pm \\
7.26\end{array}$ & $\begin{array}{c}84.96 \pm \\
6.3\end{array}$ & $<0.001$ \\
\hline 10 minutes & $80.58 \pm 5.2$ & $\begin{array}{r}78 \pm \\
6.91 \\
\end{array}$ & $\begin{array}{c}80.52 \pm \\
8.16 \\
\end{array}$ & $<0.001$ \\
\hline 15 minutes & $77.62 \pm 4.44$ & $\begin{array}{c}76.82 \pm \\
6.54\end{array}$ & $\begin{array}{c}78.78 \pm \\
8.4\end{array}$ & 0.130 \\
\hline 20 minutes & $76.32 \pm 4.93$ & $\begin{array}{c}75.88 \pm \\
6.59\end{array}$ & $\begin{array}{c}75.74 \pm \\
9.57\end{array}$ & 0.007 \\
\hline $\begin{array}{r}\text { Table 3. Con } \\
\text { Gr }\end{array}$ & ingi & lic Blood & $\begin{array}{l}\text { ssure acrc } \\
(N=150)\end{array}$ & Three \\
\hline
\end{tabular}

The mean diastolic blood pressure Thiopentone group within before induction was $79.18 \pm 6.56$, it was $76.66 \pm 6.14$ immediately after induction, it was $84.48 \pm 5.92$ in 1 minute after ECT, it was $82.96 \pm 5.45$ in 5 minutes, it was $80.58 \pm 5.2$ in 10 minutes, it was $77.62 \pm 4.44$ in 15 minutes and $76.32 \pm$ 4.93 in 20 minutes.

The mean diastolic blood pressure Propofol group within before induction was $77.44 \pm 6.89$, it was $74.28 \pm 7.36$ immediately after induction, it was $82.78 \pm 7.48$ in 1 minute after ECT, it was $79.28 \pm 7.26$ in 5 minutes, it was $78 \pm 6.91$ in 10 minutes, it was $76.82 \pm 6.54$ in 15 minutes and $75.88 \pm$ 6.59 in 20 minutes.

The mean diastolic blood pressure in Etomidate group before induction was $74.8 \pm 9.62 \mathrm{mmHg}$, it was $72.84 \pm 9.14$ mmHg immediately after induction, it was $91 \pm 7.53$ in 1 minute after ECT, it was $84.96 \pm 6.3$ in 5 minutes, it was 80.52 \pm 8.16 in 10 minutes, it was $78.78 \pm 8.4$ in 15 minutes and $75.74 \pm 9.57$ in 20 minutes.

Maximum fall in Diastolic blood pressure after induction is seen with propofol group and least fall in etomidate group, which is statistically significant $(\mathrm{P}$ value $<0.01)$ except at 15 minutes.

\begin{tabular}{|c|c|c|c|c|}
\hline Heart Rate & $\begin{array}{c}\text { Thiopenton } \\
\text { e }\end{array}$ & $\begin{array}{c}\text { Propofo } \\
\text { l }\end{array}$ & $\begin{array}{c}\text { Etomidat } \\
\text { e }\end{array}$ & $\begin{array}{c}\text { P } \\
\text { value }\end{array}$ \\
\cline { 2 - 4 } & Mean \pm SD & $\begin{array}{c}\text { Mean } \pm \\
\text { SD }\end{array}$ & $\begin{array}{c}\text { Mean } \pm \\
\text { SD }\end{array}$ & \\
\hline Before & $86.18 \pm 9.05$ & $88.78 \pm$ & $91.36 \pm$ & $\mathbf{0 . 1 5 6}$ \\
induction & & 9.11 & 13.19 & \\
\hline Immediatel & $93.96 \pm$ & $95.88 \pm$ & $92.14 \pm$ & $<0.00$ \\
y after & 13.05 & 10.77 & 11.92 & 1 \\
induction & & & & \\
\hline 1 min after & $115.4 \pm 9.89$ & $114.5 \pm$ & $94.24 \pm$ & $<0.00$ \\
ECT & & 9.75 & 12.32 & 1 \\
\hline 5 minutes & $101.4 \pm 8.63$ & $101.4 \pm$ & $94.9 \pm$ & $<0.00$ \\
& & 8.63 & 11.03 & 1 \\
\hline 10 minutes & $96.4 \pm 7.05$ & $95.74 \pm$ & $93.94 \pm$ & $<0.00$ \\
& & 7.5 & 10.97 & 1 \\
\hline 15 minutes & $93.32 \pm 8.05$ & $92.92 \pm$ & $94.08 \pm$ & $<0.00$ \\
& & 7.74 & 11.72 & 1 \\
\hline 20 minutes & $86.04 \pm 7.05$ & $85.78 \pm$ & $91.36 \pm$ & 0.174 \\
& & 6.8 & 12.97 & \\
\hline \multicolumn{5}{|c|}{ Table 4. Comparison of Heart Rate across Three Groups at } \\
& & & \\
\hline
\end{tabular}


The mean heart rate in Thiopentone group before induction was $86.18 \pm 9.05$, it was $93.96 \pm 13.05$ immediately after induction, it was $115.4 \pm 9.89$ in 1 minute after ECT, it was $101.4 \pm 8.63$ in 5 minutes, it was $96.4 \pm 7.05$ in 10 minutes, it was $93.32 \pm 8.05$ in 15 minutes and $86.04 \pm 7.05$ in 20 minutes.

The mean heart rate in Propofol group before induction was $88.78 \pm 9.11$, it was $95.88 \pm 10.77$ immediately after induction, it was $114.5 \pm 9.75$ in 1 minute after ECT, it was $101.4 \pm 8.63$ in 5 minutes, it was $95.74 \pm 7.5$ in 10 minutes, it was $92.92 \pm 7.74$ in 15 minutes and $85.78 \pm 6.8$ in 20 minutes.

The mean heart rate in Etomidate group before induction was $91.36 \pm 13.19$, it was $92.14 \pm 11.92$ immediately after induction, it was $94.24 \pm 12.32$ in 1 minute after ECT, it was $94.9 \pm 11.03$ in 5 minutes, it was $93.94 \pm 10.97$ in 10 minutes, it was $94.08 \pm 11.72$ in 15 minutes and $91.36 \pm 12.97$ in 20 minutes.

Values measured before induction is considered as baseline (Table 4).

\begin{tabular}{|c|c|c|c|c|}
\hline $\begin{array}{c}\text { Seizure } \\
\text { Duration } \\
\text { (In Secs) }\end{array}$ & $\begin{array}{c}\text { Thiopentone } \\
\text { Mean } \pm \text { SD }\end{array}$ & $\begin{array}{c}\text { Propofol } \\
\text { Mean } \pm \text { SD }\end{array}$ & $\begin{array}{c}\text { Etomidate } \\
\text { Mean } \pm \text { SD }\end{array}$ & $\begin{array}{c}\mathbf{P} \\
\text { value }\end{array}$ \\
\hline $\begin{array}{c}\text { Duration } \\
\text { (In Secs) }\end{array}$ & $32.96 \pm 6.24$ & $25.82 \pm 3$ & $45.38 \pm 7.78$ & $<0.001$ \\
\hline Table 5. Comparison of Seizure Duration (in seconds) \\
across Three Groups at Different Time Periods $(\boldsymbol{N}=\mathbf{1 5 0})$ \\
\hline
\end{tabular}

The mean seizure duration thiopentone group was 32.96 \pm 6.24 , Propofol group was $25.82 \pm 3$ and Etomidate group was $45.38 \pm 7.78$. The difference across three groups was statistically significant (P value $<0.001$ ) (Table 5 ).

\section{DISCUSSION}

Electroconvulsive therapy was administered in patients without anaesthesia or muscle relaxation, which caused many adverse effects like fracture of vertebra etc. But with the advent of hypnotic drugs and muscle relaxants, the aforesaid problems were avoided. We chose to compare the effects of Propofol, Thiopental and Etomidate in a tertiary care facility such as our institution. The patients in all the three groups were comparable in terms of age $(\mathrm{P}=0.064)$ and gender distribution $(\mathrm{P}=0.602)$. The mean height across all the three groups was comparable $(\mathrm{P}=0.168)$. The mean weight across the three groups was comparable $(\mathrm{P}=0.497)$.

We measured the change in haemodynamic parameters such as systolic blood pressure, diastolic blood pressure and heart rate. We also measured the duration of seizures in all three groups. The monitoring of haemodynamic parameters were studied immediately after induction, 1 minute, 5 minutes, 10 minutes, 15 minutes and 20 minutes after ECT.

We observed the initial fall in systolic blood pressure after induction in all the groups. But the fall in blood pressure is more in Propofol group. This is supported by the results conducted by Altaf Hussain Mir et al. ${ }^{2}$ The fall in blood pressure with Thiopentone is moderate. The fall in blood pressure is least in the Etomidate group.3-6 The change in blood pressure across the groups is statistically significant.

Same trend is observed with diastolic blood pressure also with maximum fall in blood pressure after induction is seen with Propofol group and least fall in Etomidate group. The change in diastolic blood pressure across the three groups is statistically significant ( $\mathrm{P}$ value $<0.001$ ).

The change in heart rate across three groups also is statistically significant with maximum change seen in Thiopentone group than Propofol group ( $\mathrm{P}$ value $<0.001$ ) The change in heart rate is least with Etomidate group. This similar study is conducted by Carolyn Hoyer et al. ${ }^{9}$

Regarding seizure duration, the duration of seizures is shorter with Propofol group (25.82 \pm 3 s) than with Thiopentone group (32.96 $\pm 6.24 \mathrm{~s})$. But maximum duration of seizures is seen in Etomidate group (45.38 $\pm 7.78 \mathrm{~s}$ ). This is supported by the study conducted by the study conducted by Geretsegger et al ${ }^{7}$ and Altaf Hussain Mir et al. ${ }^{2}$

\section{CONCLUSION}

From our study, we can conclude that out of the three drugs studied, Etomidate offers better haemodynamic stability causing less change in blood pressure and heart rate compared with Propofol and Thiopentone. Also, Etomidate interferes less with the seizure activity, thereby increasing the seizure duration which is of utmost importance in electroconvulsive therapy.

Hence, Etomidate can be used as an alternative for Propofol and Thiopentone in modified electroconvulsive therapy.

\section{REFERENCES}

[1] Crowley K, Pickle J, Dale R, et al. A critical examination of bifrontal electroconvulsive therapy: clinical efficacy, cognitive side effects and directions for future research. Journal of ECT 2008;24(4):268-71.

[2] Mir AH, Shah NF, Din MU, et al. Effectiveness of sodium thiopentone, propofol and etomidate as an ideal intravenous anesthetic agent for modified electroconvulsive therapy. Saudi Journal of Anaesthesia 2017;11(1):26-31.

[3] Shah PJ, Dubey KP, Watti C, et al. Effectiveness of thiopentone, propofol and midazolam as an ideal intravenous anaesthetic agent for modified electroconvulsive therapy: a comparative study. Indian Journal of Anaesthesia 2010;54(4):296-301.

[4] Zahavi GS, Dannon P. Comparison of anesthetics in electroconvulsive therapy: an effective treatment with the use of propofol, etomidate and thiopental. Neuropsychiatric Disease and Treatment 2014;10:383-9.

[5] Bauer J, Hageman I, Dam H, et al. Comparison of propofol and thiopental as an anesthetic agents for electroconvulsive therapy: a randomized, blinded comparison of seizure duration, stimulus charge, clinical effect and cognitive side effects. Journal of ECT 2009;25(2):85-90.

[6] Geretsegger C, Nickel M, Judendorfer B, et al. Propofol and methohexital as anesthetic agents for electroconvulsive therapy randomized, double-blind comparison of electroconvulsive therapy seizure quality, therapeutic efficacy and cognitive performance. Journal of ECT 2007;23(4):239-43.

[7] Geretsegger C, Rochowanski E, Kartnig C, et al. Propofol and methohexital as anesthetic agents for electroconvulsive therapy (ECT): a c comparison of seizure-quality measures and vital signs. Journal of ECT 1998;14(1):28-35. 


\section{Jemds.com}

[8] Zaidi NA, Khan FA. Comparison of thiopentone sodium and propofol for electro convulsive therapy (ECT). Journal of Pak Med Assoc 2000;50(2):60-3.

[9] Hoyer C, Kranaster L, Janke C, et al. Impact of the anesthetic agents Ketamine, etomidate, thiopental and propofol on seizure parameters and seizure quality in electroconvulsive therapy: a retrospective study. Eur Arch Psychiatry Clin Neurosci 2014;264(3):255-61.

\section{Original Research Article}

[10] Ingram A, Schweitzer I, Ng CH, et al. A comparision of propofol and thiopentone use in electroconvulsive therapy: cognitive and efficacy effects. J ECT 2007;23(3):158-62.

[11] Gabor G, Judit T, Zsolt I. Comparision of propofol and etomidate regarding impact on seizure threshold during electroconvulsive therapy in patients with schizophrenia. Neuropschopharmacology J Hungary 2007;9(3):125-30. 